\title{
製造業における「目で見る管理」
}

〜設備管理のユニバーサル化〜

渡辺 高志（株式会社 J I PMソリューション）

Visual Control for Manufacturing

Universalization of Equipment Control

Takashi WATANABE (JIPM-Solutions Co., Ltd)

\section{1. 目で見る管理と目で見る表示は違う}

\section{1 目で見る管理と表示の例}

目で見る管理とは、管理対象物の果たす心゙き機 能や役割の働き状態、つまり管理対象物の働き方 が正常か異常かを人間一働きかける仕組み・技術 である。

目で見る表示とは、管理対象物の案内役であり、 管理対象物の果たすべき機能や役割が、現在正常 に発揮されているか否かは問わないものである。
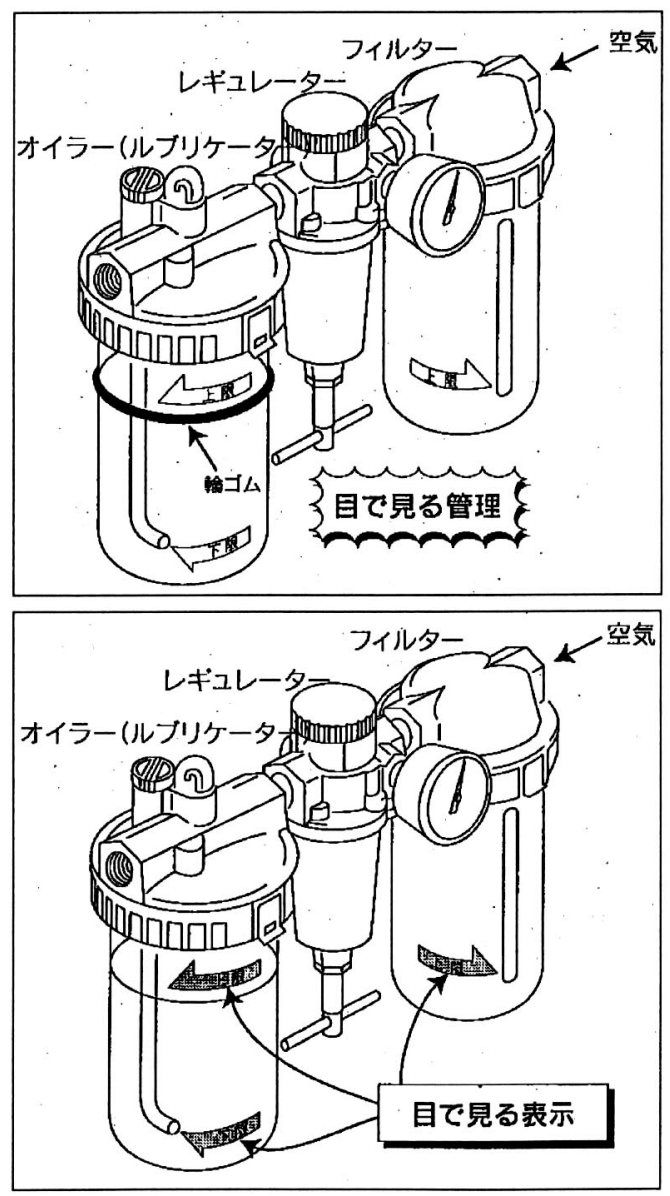

\section{2 目で見る管理の定義}

目で見る管理とは、「管理対象物が自ら異常と 判断し、異常自身がその発生を人間に働きかけ、
異常への処置行動を的確に人間に行わせる仕組 み」である。

この定義は、人的エラーの予防と管理対象物の 正常・異常の視覚化による、故障や不良などのト ラブル予防を意図している。いわゆる、人間が生 まれながら持っている “特性的弱点の補完” の意 味がある。

\section{2.目で見る管理の本質}

言葉には意味だけでなく、心(本質)が存在する ものである。目で見る管理の定義にいう「心」は “人間へのやさしさの追求” であり、人間尊重そ のものである。人間をムリ、ムダ、ムラから解放 させ、「ラクになってほしい」と願う心である。下 図では人間が抱く欲求は 5 つであり、下位の欲求 が満足寸ることで、上位の欲求が生まれるとされ ている。ラクになるとは、この5つの欲求のうち 生理的欲求と安全・安定欲求を満たすことである。 生理的欲求の満足とは、ムリからの解放であり、 安全欲求の満足とは、ムダ、ムリからの解放であ る。

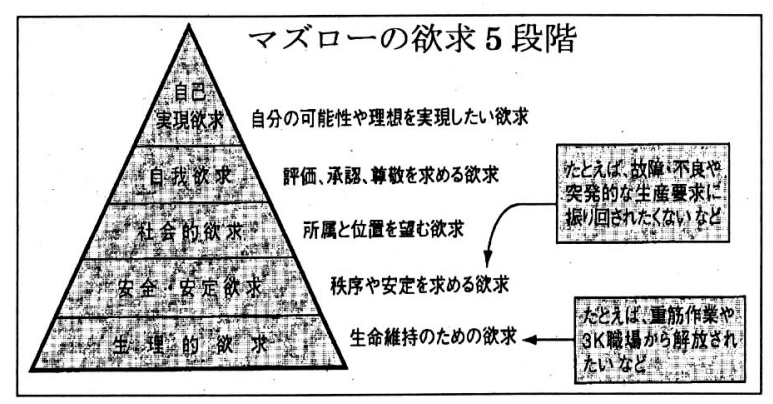




\section{3.目で見る管理のアクションプログラム}

4 つのフェーズと 7 つのアプローチ

ここでは、4つのフェーズについて解説する。

のエーズI：目で見る管理対象物の顕在化

管理の急所(劣化部位)の発掘とその基本条件 の整備。

のェーズ II：目で見る管理対象物の可視化 管理の急所の物理的潜在欠陥の摘出と対策。

・分解しないと見えない $\rightarrow$ 透明化

・取付けいちが悪くて見えない、 点検しにくい $\rightarrow$ 視覚化 管理の急所の基本条件の効率的な維持。

○ェーズ III：目で見る管理対象物の色彩化 基本条件上における管理の急所の正常と異常 の判定基準化(定量化)および異常処置方法の 標準化と訓練。

基本条件、加工条件における管理の急所の 正常・異常・危険判定の色彩化による点検 活動の容易化と効率化。

○ェーズIV : 目で見る管理の維持とレベルアップ 管理の急所の基本条件と加工条件の維持の 本基準化した異常処置方法の遵守および定着。 長寿命化、集約化、簡素化、精度アップによ る、長くつき合える目で見る管理の実現と、 目で見ないで済む管理の追求。

\section{4.異常に強いオペレーターになる}

目で見る管理の定義は、前述したとおり、『管理 対象物が自ら異常と判断し、異常自身がその発生 を人間に働きかけ、異常への処置行動を的確に人 間に行わせる仕組み』である。一言で言うならば、

“異常のシグナルを人間へ伝える仕組み”となる。 ここで理解しておかなければならない点が 1 つ ある。それは、目で見る管理とは、あくまでも異 常を人間へ伝えるための手段であり、その異常へ の処置行動はやはり人間に頼らざるを得ないとい う点である。つまり、「見えてどうするか、その 異常の処置行動が目で見る管理を活か寸ポイント でもあるし、また逆に目で見る管理を殺すウィー
クポイントでもある。

目で見る管理の 3 つの成立条件

(1)あいまいさのない正常な状態の整備

(2)見える・判る・働きかける仕組み

(3)アクション(処置) 要重
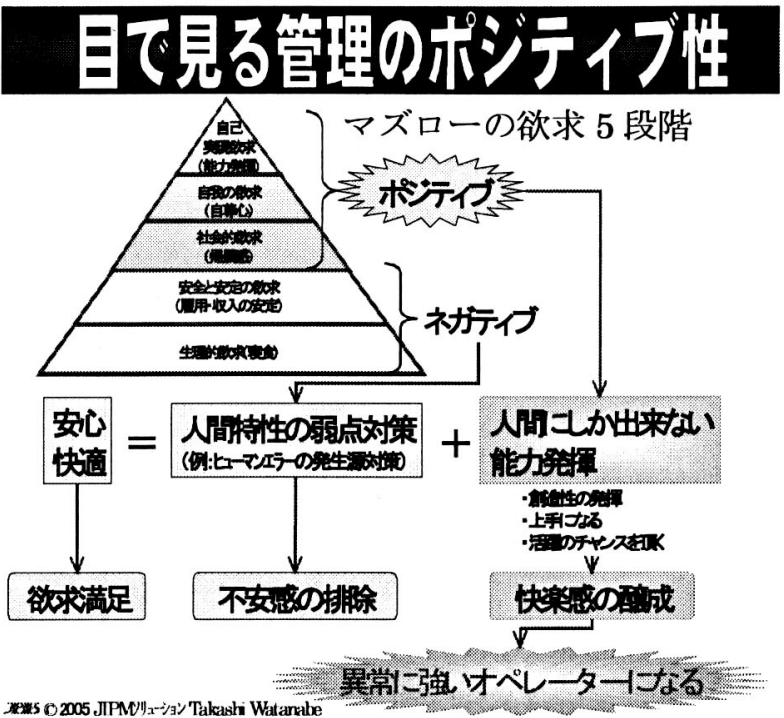

前述したとおり、目で見る管理とは“人間への やさしさの追求”である。つまり、「マズローの欲 求 5 段階」の下位の 2 つを満たすものである。つ まり、目で見る管理のネガティブ性がここにある。

しかし、目で見る管理にはポジティブ性も存在 する。つまり、人間にしか出来ない能力発揮によ る自己実現の要素を持っている。異常に強いオぺ レーターになることは、この点を意味している。

\section{連絡先： $\overline{1} 105-0011$}

東京都港区芝公園 3-1-38 秀和芝公園三丁目ビル $5 \mathrm{~F}$ 株式会社 J I PMソリューション

E-mail : center@jipms.jp

TEL : 03-3433-0353 / FAX : 03-3433-8666 